\title{
MODEL BISNIS AGROFARM CIANJUR \\ (Studi Kasus Kelompok Tani Agro Segar, pada P4S Agrofarm Cianjur, Desa Ciherang, Kabupaten Cianjur, Provinsi Jawa Barat)
}

\author{
Business Model of Cianjur Agrofarm \\ (Case Study of Agro Segar Farmers Group on P4S Cianjur Agrofarm, Ciherang Village, \\ Cianjur Regency, West Java Province) \\ Niken Hikmawati* dan Gema Wibawa Mukti \\ Program Studi Agribisnis, \\ Fakultas Pertanian, Universitas Padjadjaran \\ *Kontak penulis: nikenhikmawati@gmail.com
}

\begin{abstract}
Indonesian society today does not show a great interest in the agricultural sector. Even though there is a regency in West Java which has the highest population working in the agricultural sector, that is Cianjur Regency. Cianjur Agrofarm is one of the P4S (Pusat Pelatihan Pertanian dan Pedesaan Swadaya= Self-Help Agricultural and Rural Training Center) which does train cultivation and marketing of horticultural commodities of the Agro Segar farmers group. The objective of this research is to look at the business model of the Cianjur Agrofarm. This research uses qualitative research design with case study technique. The analytical tool used is valuing network mapping with Holo Mapping analysis, and Business Model Canvas. The description of the business model is obtained through the business design process of storytelling technique, visual thinking, and prototyping. Based on the results of research, the business model of Agrofarm Cianjur is quite advanced and can be used as an inspiration for agricultural actors. Agrofarm Cianjur needs to add partners and resources and update the administrative accounting which is still manual.
\end{abstract}

Keywords: Canvas Business Model; Farmers Group; P4S; Value Network Mapping.

Sitasi: Hikmawati, N. dan G.W. Mukti, 2018. Model Bisnis Agrofarm Cianjur, JSEP 14(2): 93 $-104$.

\section{Pendahuluan}

Masyarakat Indonesia pada saat ini tidak menunjukkan minat yang besar terhadap sektor pertanian terlihat dari menurunnya jumlah rumah tangga petani di Indonesia. Provinsi Jawa Barat merupakan salah satu provinsi yang memberikan sumbangan terbesar terhadap penurunan rumah tangga petani. Data Badan Pusat Statistik Provinsi Jawa Barat (2017) menunjukkan penduduk berumur 15 tahun ke atas yang bekerja menurut lapangan usaha di Jawa Barat tahun 2016 adalah sebesar 19.202.038 jiwa. Data tersebut memperlihatkan bahwa sektor pertanian menempati posisi terendah dalam lapangan usaha dengan jumlah 3.154.509 jiwa. Rendahnya persentase masyarakat yang bekerja pada sektor pertanian di Provinsi Jawa Barat terjadi karena pesatnya urbanisasi, 
serta sedikitnya jumlah petani usia muda. Pesatnya urbanisasi di Provinsi Jawa Barat berakibat pada beralihnya sebagian lahan pertanian menjadi daerah permukiman dan fasilitas umum, sehingga membuat jumlah rumah tangga pertanian semakin sedikit. Dalam hal sumberdaya manusia, sedikitnya jumlah petani usia muda merupakan faktor yang menjadi penyebab cukup tinggi dalam menurunnya rumah tangga petani (Susilowati, 2016).

Walaupun demikian, terdapat kabupaten di Jawa Barat yang menempati urutan pertama dengan jumlah penduduk tertinggi yang bekerja pada sektor pertanian yaitu Kabupaten Cianjur (BPS Provinsi Jawa Barat, 2017). Sektor pertanian berkontribusi sebanyak 35,97\% dalam lapangan pekerjaan utama di Kabupaten Cinajur, yang merupakan persentase tertinggi, jika dibandingkan dengan sektor lainnya. Hal tersebut menggambarkan bahwa sektor pertanian berperan sebagai mata pencaharian utama di Kabupaten tersebut. Dengan tingginya minat masyarakat Cianjur terhadap sektor pertanian, maka Kabupaten ini merupakan salah satu sentra pertanian di Jawa Barat yang sering dijadikan contoh bagi daerah lain. Salah satu bukti nyata dari hal tersebut adalah dengan banyak berdiri P4S (Pusat Pelatihan Pertanian dan Pedesaan Swadaya) di daerah ini sebagai salah satu sarana dalam meningkatkan sumberdaya manusia (Kereh, 2015; Prasetyo, 2016).

Diantara P4S yang bergerak dalam komoditas hortikultura adalah P4S Agrofarm Cianjur. P4S ini merupakan salah satu P4S yang telah mendapat Sertifikasi Prima tahun 2011 yang dikeluarkan oleh Dinas Pertanian Tanaman Pangan Provinsi Jawa Barat, dengan Nomor Registrasi GAP. 01-32.03.41-II.52 dan Nomor Sertifikasi: 32/03-3-01-II052-021-12/2011.

Beberapa studi yang pernah dilakukan berkaitan dengan P4S Agrofarm Cianjur, diantaranya: Hasana, N. dan Hanum, L., (2016); Sidiqon, K. dan Raflis, H. (2017); dan Hasral, M. dan Ibrahim, H. (2018). Penelitian yang mereka lakukan di P4S Agrofarm Cinajur tersebut mengenai harga jual, saluran distribusi, budidaya dan segmentasi pasar dari komoditi hortikultura yang dikembangkan di Agrofarm tersebut. Belum ditemukan adanya studi mengenai bisnis model yang menjadi acuan dalam operasi dan pengembangan P4S Agrofarm tersebut. Berlatar hal itu, maka penelitian mengenai bisnis modelnya menjadi penting untuk dilakukan.

P4S Agrofarm Cianjur merupakan pusat pelatihan bagi petani magang maupun siswa dan mahasiswa magang dalam bidang pertanian. Agrofarm Cianjur bukan hanya berdiri sebagai P4S, namun di dalamnya juga terdapat kelompok tani dengan nama Agro Segar yang melakukan aktivitas usahatani komoditas hortikultura. P4S Agrofarm Cianjur dan Kelompok Tani Agro Segar merupakan satu kesatuan dengan fokus dan fungsi yang berbeda. Fokus dan fungsi dari P4S adalah melakukan pelatihan dalam budidaya dan pemasaran usahatani komoditas hortikultura, sedangkan fokus dan fungsi dari Kelompok Tani Agro Segar adalah melakukan produksi komoditas hortikultura khususnya tanaman sayuran, serta sebagai supplier pada swalayan dan rumah makan di daerah Jakarta dan sekitarnya.

Kelompok Tani Agro Segar beranggotakan 21 orang petani dengan luas lahan yang dimiliki seluas 8,5 hektar dan mengusahakan beragam komoditas hortikultura. Terdapat kurang lebih 50 jenis komoditas sayuran konvensional maupun organik yang 
diusahakan, termasuk sayuran eksotik Jepang dan Korea yang mendominasi produksi kelompok tani ini. Kelompok Tani Agro Segar sangat memperhatikan peluang pasar dari produksi tanaman eksotik tersebut, karena tanaman eksotik Jepang dan Korea masih jarang dibudidayakan oleh petani pada umumnya, serta permintaan pasar yang terjadi secara terus-menerus.

Setiap tahunnya, P4S Agrofarm Cianjur selalu menerima peserta pelatihan yang datang silih berganti. Diantara peserta pelatihan tersebut yaitu berasal dari petani magang dan siswa atau mahasiswa magang dalam bidang pertanian. P4S Agrofarm Cianjur maupun Kelompok Tani Agro Segar telah mendapat berbagai penghargaan, diantaranya penghargaan Gubernur Jawa Barat sebagai Kelompok Tani Teladan Tingkat Provinsi Jawa Barat, penghargaan Gubernur Jawa Barat sebagai Kelompok Tani Berprestasi Tingkat Provinsi Jawa Barat serta penghargaan Menteri Pertanian sebagai P4S Berprestasi Tingkat Nasional. Dengan terbentuknya Agrofarm Cianjur sebagai satu kesatuan dengan fokus dan fungsi yang berbeda, hal tersebut tentunya membuat Kelompok Tani Agro Segar dapat memberikan inspirasi serta berpartisipasi aktif dalam meningkatkan kemampuan usaha petani, dengan menjadikan hasil dari usahatani Agro Segar sebagai contoh nyata dalam bisnis pertanian.

Penelitian ini akan melihat model bisnis yang dilakukan oleh Agrofarm Cianjur dengan menggunakan model bisnis kanvas. Penggunaan model bisnis kanvas dapat memberikan gambaran mengenai model bisnis suatu perusahaan dan hubungan yang terjadi antar blok dengan cara yang lebih atraktif.

\section{Metode Penelitian}

Penelitian ini menggunakan desain penelitian kualitatif dengan teknik studi kasus (Sugiyono. 2014). Alat analisis yang digunakan adalah pemetaan jaringan nilai dengan analisis Holo Mapping (Allee, 2000) dan Business Model Canvas yang dikembangkan oleh Osterwalder dan Pigneur (2012) digunakan untuk mendeskripsikan model bisnis yang diterapkan. Penggambaran model bisnis didapatkan melalui proses desain bisnis dengan teknik bercerita, berpikir visual, serta prototyping. Terdapat sembilan blok yang dianalisis di setiap elemen Business Model Canvas, yaitu value propositions, key activities, key resources, key partnerships, customer segments, customer relationships, channels, cost structure dan revenue streams (Osterwalder dan Pigneur, 2012).

\section{Hasil dan Pembahasan}

\section{Pemetaan Jaringan Nilai}

Model bisnis Agrofarm Cianjur digambarkan melalui Business Model Canvas yang sebelumnya dipetakan dengan menggunakan pemetaan jaringan nilai Holo Mapping (Allee, 2000). Pemetaan jaringan nilai merupakan nilai hubungan antara pemangku kepentingan yang terlibat dalam kegiatan usahatani yang dijalankan oleh Agrofarm Cianjur. Pertukaran nilai dengan beberapa relasi Agrofarm Cianjur yang terdapat dalam aliran yang berbentuk produk maupun jasa merupakan sebuah pertukaran yang menghasilkan biaya dan pendapatan. Pertukaran nilai itu dapat berupa aliran pengetahuan, pembinaan, sharing informasi, dan kemitraan (Lihat Gambar 1). 


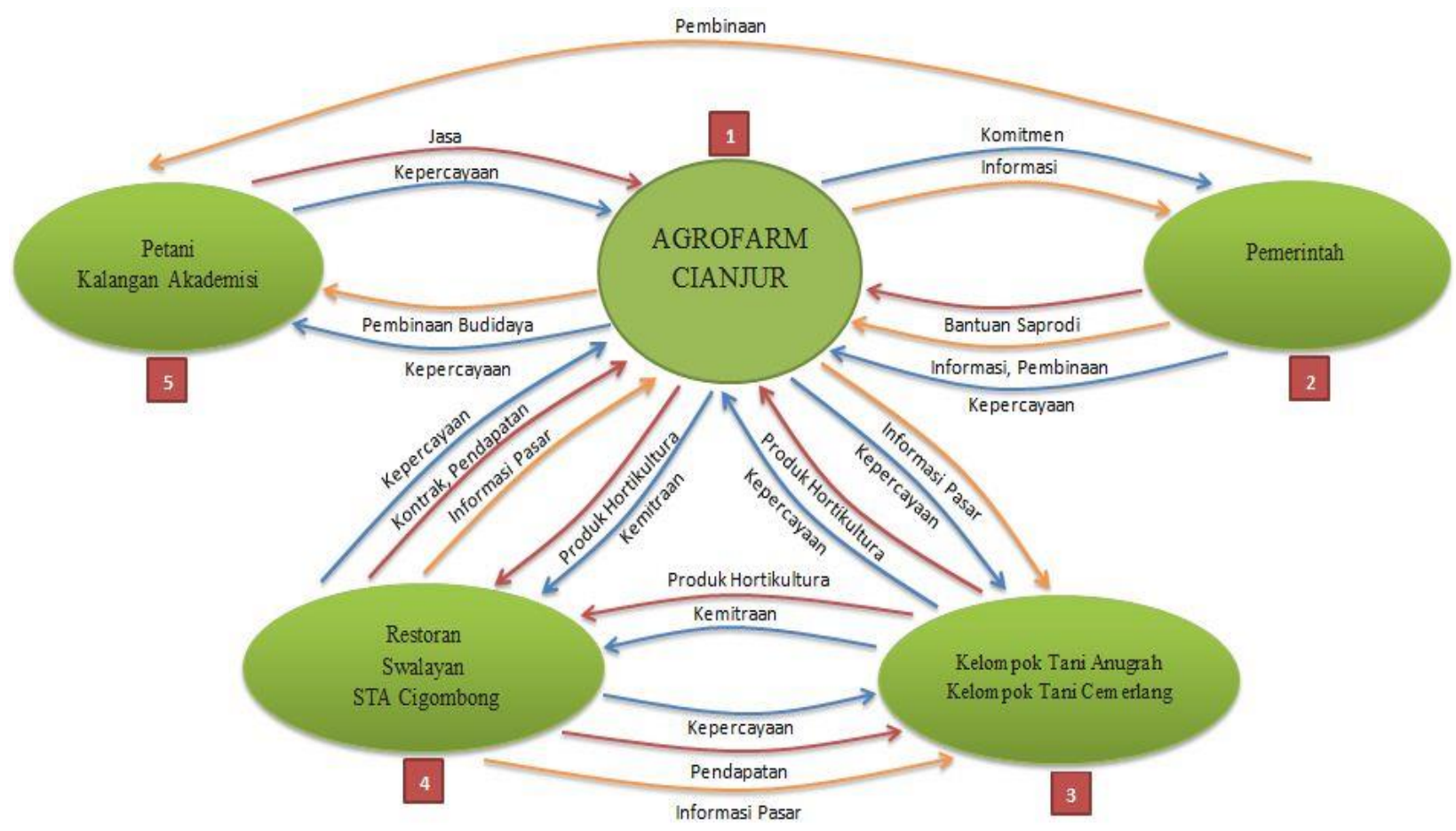

Gambar 1. Holo Mapping Pertukaran Nilai Agrofarm Cianjur

Keterangan:

Panah Merah : Barang, Jasa, Pendapatan

Panah Orange : Pengetahuan

Panah Biru : Manfaat Imateriil yang Tidak dapat Diukur

Hubungan yang terjalin antara Agrofarm Cianjur dengan pemerintah diantaranya adalah hubungan dalam aliran pertukaran barang, jasa dan pendapatan yang meliputi bantuan sarana produksi pertanian dari Dinas Pertanian Kabupaten Cianjur. Terdapat aliran pengetahuan dari lembaga penyuluh tingkat kabupaten, Dinas Pertanian, Penyelenggaraan pameran dari instansi pertanian, dan pasar tani. Selain itu, terdapat juga aliran manfaat yang tidak berwujud berupa komitmen dan kepercayaan yang diberikan oleh pemerintah.

Relasi yang terjalin antara Agrofarm Cianjur dengan Kelompok Tani Anugrah dan Kelompok Tani Cemerlang yakni berupa aliran pertukaran barang, jasa dan pendapatan dari produk hortikultura. Agrofarm Cianjur melakukan kerjasama dengan kelompok tani tersebut untuk memenuhi permintaan konsumen, jika suatu saat terjadi pertambahan permintaan secara mendadak. Pada aliran pengetahuan, Agrofarm Cianjur memberikan pengetahuan kepada kelompok tani tersebut mengenai informasi pasar. Aliran manfaat yang tidak berwujud terjadi berupa pertukaran kepercayaan antara Agrofarm Cianjur dengan Kelompok Tani Anugrah dan Kelompok Tani Cemerlang.

Agrofarm Cianjur menjadi supplier untuk swalayan dan restoran di daerah Jakarta dan sekitarnya secara kontinu. Ketika Agrofarm Cianjur mengalami kelebihan produksi, maka produk tersebut dipasarkan melalui STA (Sub Teminal Agribisnis) Cigombong, 
sehingga Agrofarm Cianjur tidak perlu khawatir bahwa produknya tidak akan terjual. Aliran pertukaran nilai yang terjadi antara Agrofarm Cianjur dengan konsumen tersebut adalah berupa aliran pertukaran barang, jasa dan pendapatan. Agrofarm Cianjur menyalurkan hasil produksi kepada konsumen, sedangkan konsumen memberikan kontrak dan pendapatan. Pada aliran pengetahuan, konsumen memberikan informasi pasar kepada Agrofarm Cianjur. Manfaat yang tidak berwujud yang terbentuk berupa kemitraan dan kepercayaan dari konsumen.

Antara mitra kelompok tani dengan mitra konsumen dari Agrofarm Cianjur terbentuk hubungan berupa pasokan produksi untuk memenuhi permintaan konsumen. Sedangkan untuk konsumen tidak tetap seperti STA Cigombong, Kelompok Tani Anugrah maupun Kelompok Tani Cemerlang menjual hasil produksinya kepada STA Cigombong, sehingga menciptakan pertukaran nilai antara mitra konsumen dengan mitra kelompok tani dari Agrofarm Cianjur.

Hubungan yang terjalin antara Agrofarm Cianjur dengan petani maupun kalangan akademisi dalam bidang pertanian adalah dalam hal pelatihan budidaya dan pemasaran produk hortikutura. Aliran pertukaran nilai barang, jasa dan pendapatan, yaitu berupa jasa yang diberikan oleh petani maupun siswa atau mahasiswa yang melakukan pelatihan, karena dengan adanya peserta pelatihan yang melakukan praktik budidaya langsung di lapangan, hal tersebut membuat Agrofarm Cianjur memiliki tambahan sumberdaya manusia dalam kegiatan usaha taninya. Pada aliran pengetahuan, Agrofarm Cianjur memberikan pembinaan budidaya tanaman hortikultura dengan dibantu oleh pemerintah dalam hal ini Dinas Pertanian Kabupaten Cianjur, Dinas Ketahanan Pangan Kabupaten Cianjur dan Badan Penyuluhan Pertanian Kabupaten Cianjur. Berdasarkan aliran manfaat yang tidak berwujud, terjadi pertukaran kepercayaan antara Agrofarm Cianjur dengan peserta pelatihan yang mengikuti program pelatihan.

\section{Analisis Business Model Canvas (BMC)}

Model bisnis Agrofarm Cianjur yang digambarkan didapat melalui proses desain bisnis, serta dibantu oleh pemetaan jaringan nilai (Holo Mapping). Terdapat sembilan blok dalam model bisnis kanvas yang dideskripsikan melalui teknik desain bisnis yang berbeda-beda. Blok customer segments, value propositions, channels, customer relationships, revenue streams dan cost structure didapatkan melalui teknik bercerita dengan emphatize kemudian didefinisikan. Sedangkan pada blok key resources, key activities, dan key partnerships didapatkan melalui teknik berpikir visual dengan menggunakan pemetaan Holo Mapping. Ketika sembilan blok telah dideskripsikan, maka selanjutnya dilakukan teknik prototyping untuk menggambarkan model bisnis Agrofarm Cianjur secara menyeluruh (Anonim, 2012).

\section{Proposisi Nilai (Value Propositions)}

Value propositions merupakan suatu nilai yang membuat konsumen dapat beralih dari satu perusahaan ke perusahaan lain, dimana berisi gabungan dari manfaat-manfaat yang ditawarkan perusahaan kepada konsumen. Agrofarm Cianjur memiliki value 
propositions diantaranya dalam hal sifat baru, karena komoditas yang diproduksi oleh sebagian besar adalah sayuran eksotik Jepang dan Korea tidak sebanyak produsen tanaman hortikultura pada umumnya.

Agrofarm Cianjur menyesuaikan produk yang dihasilkan dengan kebutuhan konsumen. Diantara konsumen Agrofarm Cianjur adalah toko swalayan dan restoran yang menyediakan makanan Jepang dan Korea. Agrofarm Cianjur juga memproduksi komoditas hortikultura dalam dua jenis, yaitu organik dan anorganik dengan beragam ukuran produk yang dihasilkan. Konsumen dari toko swalayan pada umumnya meminta produk yang berukuran lebih besar dibandingkan dengan konsumen dari restoran.

Agrofarm Cianjur memiliki value propositions dengan membersihkan terlebih dahulu produk yang akan dijual kepada konsumen. Setelah bersih, selanjutnya dilakukan pengemasan yang disesuaikan dengan masing-masing bentuk komoditas. Dengan keadaan produk yang telah dikemas, sangat memudahkan toko swalayan untuk menyampaikan hasil produksinya kepada konsumen akhir. Selain itu Agrofarm Cianjur juga memberikan kemudahan kepada pelanggannya dengan mengirim produk langsung kepada konsumen. Dari segi harga, value propositions yang dimiliki Agrofarm Cianjur adalah harga yang terjangkau bagi pihak konsumen dan tentunya menguntungkan juga bagi pihak produsen. Sistem penetapan harga adalah dengan dilakukannya kontrak pada awal terikat sistem kerjasama antara supplier-buyer dan penetapan harga akan diperbaharui setiap tiga bulan sekali untuk menyesuaikan dengan keadaan harga produksi dan penjualan pada masa itu.

\section{Aktivitas Kunci (Key Activities)}

Key activities menggambarkan hal-hal terpenting yang harus dilakukan oleh perusahaan agar model model bisnis pada perusahaan tersebut dapat berjalan dengan baik. Setiap model bisnis memiliki aktivitas-aktivitas utama. Berdasarkan aktivitas yang dilakukan, Agrofarm Cianjur mempunyai aktivitas berupa pengadaan bahan yang diperlukan dari pemasok, pengolahan dalam proses produksi, penyaluran produk jadi atau jasa kepada konsumen serta aktivitas administrasi.

Aktivitas produksi pada Agrofarm Cianjur dimulai dari pengadaan sarana produksi pertanian hingga kegiatan budidaya tanaman hortikultura di lahan. Pengelolaan pascapanen memanfaatkan waktu di malam hari dengan melakukan kegiatan proses packaging hasil produksi. Kegiatan pengemasan ini terdiri dari pembersihan produk dari kotoran, penimbangan produk, pengisian kemasan dan penutupan kemasan dengan menggunakan alat wrapping maupun dengan solatip khusus sayuran.

Kegiatan terakhir yang dilakukan adalah aktivitas distribusi produk kepada konsumen. Produk Agrofarm Cianjur didistribusikan ke swalayan dan restoran yang berlokasi di Jakarta dan sekitarnya. Selain itu, terdapat aktivitas administrasi yang dilaksanakan yang meliputi pembukuan dan pencatatan segala macam transaksi selama berjalannya kegiatan usahatani. Kegiatan pencatatan dan pembukuan dilakukan setiap berjalannya aktivitas produksi sampai penjualan dengan mencatat ke dalam buku secara manual (tulis tangan) dengan tidak melakukan back up data apabila buku tersebut rusak atau hilang. 


\section{Sumberdaya Utama (Key Resources)}

Key resource menggambarkan aset-aset terpenting yang diperlukan agar sebuah model bisnis dapat berfungsi, sekaligus sebagai penunjang dalam kegiatan usaha. Sumberdaya utama terbagi menjadi empat kategori, yaitu sumberdaya fisik, intelektual, manusia, dan finansial. Sumberdaya fisik yang dimiliki oleh Agrofarm Cianjur diantaranya bangunan kecil tempat produksi (gudang/tempat packing); alat produksi seperti timbangan elektrik, container box, meja packing, alat wrapping, dan alat pertanian lainnya; sarana produksi pertanian seperti lahan, pupuk, benih; mobil pick-up sebagai alat distribusi; fasilitas dalam pelaksanaan penyuluhan maupun kegiatan pelatihan berupa laptop, proyektor, kursi, meja kerja, dan microfon.

Sumberdaya intelektual yang dimiliki Agrofarm Cianjur adalah serifikat produk prima yang dikeluarkan oleh Dinas Pertanian Tanaman Pangan Provinsi Jawa Barat, dengan Nomor Registrasi GAP. 01-32.03.41-II.52 dan Nomor Sertifikasi: 32/03-3-01-II052-021-12/2011. Selain itu, Agrofarm Cianjur juga memiliki sertifikat pada pusat pelatihan tersebut yang diberikan kepada peserta pelatihan yang telah menyelesaikan kegiatan pelatihan. Sumberdaya manusia yang dimiliki oleh Agrofarm Cianjur diantaranya anggota Kelompok Tani Agro Segar, serta pengurus dari P4S Agrofarm Cianjur. Sumberdaya manusia yang dilibatkan bukan hanya berasal dari seluruh anggota namun juga berasal dari peserta yang mengikuti pelatihan budidaya hingga pemasaran produk hortikultura. Sumberdaya finansial pada awal dibentuk, berasal dari Dinas Pertanian Kabupaten Cianjur yang memberikan bantuan berupa barang sebagai keperluan dalam melakukan kegiatan usahatani, yaitu meja packing, timbangan elektrik, alat wrapping dan container box.

\section{Kemitraan Utama (Key Partnerships)}

Key partnerships menggambarkan hubungan kemitraan yang dilakukan oleh perusahaan kepada pihak lain untuk menunjang aktivitas bisnis yang dilakukan, serta untuk mengoptimalisasi model bisnisnya, mengurangi resiko dan memperoleh sumberdaya. Agrofarm Cianjur memiliki berbagai mitra dalam menjalankan usahanya. Mereka dibantu Dinas Pertanian Kabupaten Cianjur dalam mendapatkan modal awal berupa barang sebagai keperluan dalam melakukan kegiatan usahatani, serta memberikan wadah bagi Agrofarm Cianjur untuk memasarkan produknya melalui pameran yang diselenggarakan oleh Dinas Pertanian Kabupaten Cianjur dan yang diselenggarakan oleh Dinas Pertanian Provinsi Jawa Barat serta Kementerian Pertanian.

Agrofarm Cianjur menjalin mitra dengan kelompok tani lain untuk memenuhi kekurangan dalam pasokan produksi yang akan didistribusikan kepada konsumen. Diantara kelompok tani yang menjadi mitra yaitu Kelompok Tani Anugrah dan Kelompok Tani Cemerlang. Konsumen tetap dari Agrofarm Cianjur antara lain $\mathrm{Mu}$ Gung Hwa, K-Mart, Hanil Mart, Word Mart, Asia Mart, Ya Rae Hyang dan San Jung. Apabila mengalami kelebihan hasil produksi, maka Agrofarm Cianjur menjual produknya kepada STA (Sub Terminal Agribisnis) Cigombong. Mitra lainnya adalah penyuluh pertanian dari lembaga penyuluh dari Dinas Pertanian Kabupaten Cianjur. Penyuluhan pada umumnya dilakukan kepada anggota kelompok tani langsung, 
maupun kepada peserta pelatihan dari Agrofarm Cianjur. Saat pelatihan pertanian tengah berlangsung, Agrofarm Cianjur juga melakukan kemitraan dengan Dinas Ketahanan Pangan Kabupaten Cianjur dan Badan Penyuluhan Pertanian Kabupaten Cianjur untuk ikut serta dalam kegiatan pelatihan pertanian. Diantara peserta pelatihan berasal dari petani magang dan siswa atau mahasiswa magang dalam bidang pertanian.

\section{Segmen Pelanggan (Customer Segments)}

Agrofarm Cianjur memiliki customer segments yang termasuk ke dalam segmen pasar niche market (ceruk pasar/pasar khusus) seperti yang dikemukakan pada teori Kotler (2008), dimana Agrofarm Cianjur menargetkan kepada segmen pasar tertentu yang spesifik, pada umumnya memiliki jumlah yang sedikit serta belum terlayani dengan baik. Model bisnis ini umum ditemukan pada hubungan bisnis antara supplierbuyer, seperti pada Agrofarm Cianjur yang telah menjadi supplier pada swalayan dan restoran di daerah Jakarta dan sekitarnya.

\section{Hubungan Pelanggan (Customer Relationships)}

Hubungan pelanggan menggambarkan bagaimana perusahaan melakukan komunikasi dengan pelanggan. Customer Relationships menjalankan beberapa fungsi, yaitu customer acquisition (akuisisi konsumen); customer retention (mempertahankan konsumen); dan upselling (peningkatan penjualan). Customer relationships terbagi menjadi beberapa jenis. Dalam hal ini, Agrofarm Cianjur termasuk kepada jenis hubungan personal assistance (bantuan personal) yang didasarkan pada interaksi antar manusia. Konsumen dapat berkomunikasi dengan petugas untuk mendapatkan bantuan selama proses penjualan atau setelah selesainya aktivitas jual-beli. Berdasarkan fungsi customer acquisition dalam hubungan pelanggan, Agrofarm ini berusaha untuk menjangkau konsumen akhir dengan mengikuti berbagai pameran, yaitu pameran yang diadakan oleh Dinas Pertanian Kabupaten Cianjur, Dinas Pertanian Provinsi Jawa Barat dan Pasar Tani yang diadakan oleh Kementerian Pertanian. Pada fungsi customer retention, upaya yang dilakukan diantaranya selalu menjaga kualitas hasil produksi, sehingga konsumen akan merasa puas dengan produk yang dihasilkan. Apabila terdapat produk yang dianggap kurang memenuhi standar dari konsumen, maka produk tersebut akan dikembalikan kepada Agrofarm Cianjur. Untuk fungsi upselling pada hubungan pelanggan, Agrofarm Cianjur bermitra dengan kelompok tani di daerah tersebut untuk berjaga jika suatu saat terjadi pertambahan permintaan secara mendadak dari konsumen. Kelompok Tani yang merupakan mitra yaitu Kelompok Tani Anugrah dan Kelompok Tani Cemerlang yang berlokasi di Desa Ciherang.

\section{Saluran (Channels)}

Channels menggambarkan bagaimana sebuah perusahaan dapat berkomunikasi dengan konsumen untuk memberikan value propositions. Channels terbagi ke dalam dua jenis saluran, yaitu saluran langsung dan tidak langsung. Saluran yang digunakan dalam menjangkau konsumen diantaranya indirect selling (saluran tidak langsung), yaitu dengan menjual produksi kepada swalayan dan restoran yang telah menjadi mitra. Ketika mengalami kelebihan produksi, maka produk tersebut dipasarkan melalui STA Cigombong, sehingga tidak perlu khawatir bahwa produknya tidak terjual. 


\section{Struktur Biaya (Cost Structure)}

Struktur biaya menggambarkan semua biaya yang dikeluarkan untuk mengoperasikan model bisnis, dengan menggambarkan tentang biaya apa saja yang dikeluarkan perusahaan dalam menjalankan aktivitas bisnis. Agrofarm Cianjur memiliki struktur biaya yang termasuk pada kategori value driven (terpacu nilai). Value driven lebih mengutamakan pada penciptaan nilai agar dapat memaksimalkan kepuasan konsumen. Agrofarm Cianjur selalu mengutamakan kualitas produknya dengan harga yang terjangkau bagi konsumen serta memberikan kenyamanan dengan menerapkan sistem pengembalian produk jika terdapat produk yang berlebih atau mengalami penurunan kualitas. Cost Structure pada Agrofarm Cianjur terbagi menjadi dua karakteristik, yaitu biaya tetap dan biaya variabel. Biaya tetap meliputi biaya sewa lahan, upah pekerja dan listrik. Sedangkan biaya variabel meliputi biaya sarana produksi seperti biaya bahan baku, biaya bahan untuk pengemasan, biaya bahan bakar kendaraan serta biaya tak terduga lainnya.

\section{Arus Pendapatan (Revenue Streams)}

Revenue Streams menggambarkan uang tunai yang dihasilkan perusahaan dari setiap customer segments. Arus pendapatan dalam Agrofarm Cianjur diperoleh dari asset sale (penjualan aset). Asset sale merupakan penjualan produk dalam bentuk barang dan jasa. Dalam bentuk jasa, Agrofarm Cianjur mengadakan pelatihan pertanian untuk petani dan siswa ataupun mahasiswa dalam bidang pertanian. Dalam bentuk barang, produk dari Agrofarm Cianjur yang merupakan tanaman hortikultura dengan berbagai komoditas, tentunya memiliki harga jual yang beragam. Harga tersebut diperoleh atas kesepakatan bersama antara Agrofarm Cianjur dan konsumen dengan mempertimbangkan harga jual setiap komoditas pada masa itu.

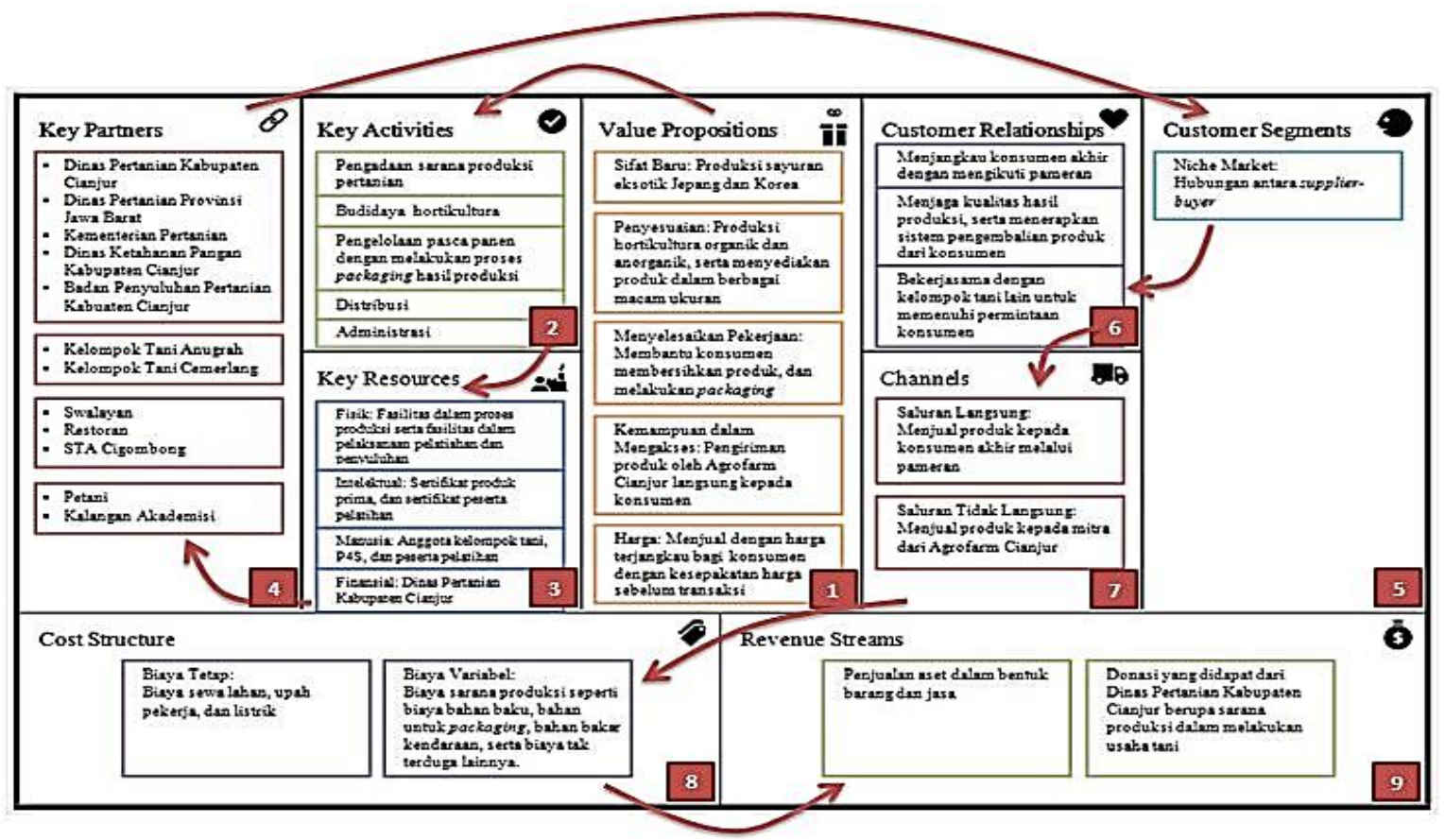

Gambar 3. Business Model Canvas Agrofarm Cianjur 


\section{Diagram Business Model Canvas (BMC)}

Berdasarkan penjelasan mengenai model bisnis dari Agrofarm Cianjur tersebut, selanjutnya menggambarkan model bisnis Agrofarm Cianjur secara keseluruhan dengan menggunakan teknik prototyping. Teknik prototyping dilakukan dengan membuat model bisnis secara manual yang akan menggambarkan secara singkat tentang model bisnis Agrofarm Cianjur melalui sebuah diagram Business Model Canvas. Gambaran dari model bisnis kanvas tersebut diharapkan dapat mempermudah anggota dari Agrofarm Cianjur dalam memahami model bisnis yang sedang dijalankan. Model bisnis Agrofarm Cianjur yang digambarkan dalam Diagram Business Model Canvas tergambar jelas pada Gambar 3.

\section{Kesimpulan}

Berdasarkan temuan di lapangan dan hasil pembahasan mengenai model bisnis Agrofarm Cianjur dengan menggunakan analisis business model canvas serta pemetaan jaringan nilai (holo mapping), model bisnis dari Agrofarm Cianjur sudah baik karena mampu memenuhi sembilan blok bangunan model bisnis kanvas. Berdasarkan blok proposisi nilai, Agrofarm Cianjur mampu memberikan proposisi nilai kepada konsumen dengan menjalankan aktivitas yang sesuai dengan adanya nilai tersebut. Mitra serta sumberdaya yang dimiliki sudah cukup memenuhi dalam pelaksanaan usahatani, namun masih perlu untuk ditingkatkan agar dapat memaksimalkan produksi. Dengan adanya pelatihan yang dijalankan oleh Agrofarm Cianjur, tentunya hal tersebut memberikan manfaat bagi semua pihak, karena bagi peserta pelatihan ilmu yang didapat dari kegiatan budidaya hingga pemasaran dari Agrofarm Cianjur dapat dipraktikkan langsung di lapangan serta dapat diterapkan dalam melakukan usahatani, sedangkan bagi Agrofarm Cianjur dengan adanya peserta pelatihan, dapat menambah sumberdaya manusia dalam menjalankan kegiatan usahatani. Saluran serta hubungan yang dimiliki antara Agrofarm Cianjur dengan konsumen sudah dijalankan dengan baik oleh Agrofarm Cianjur dalam menjangkau target konsumen. Berdasarkan struktur biaya dan arus pendapatan, aliran keuangan berjalan dengan baik, walaupun dalam pembukuan dan pencatatan administrasi masih dilakukan secara manual.

Berdasarkan blok key partnerships dan key resources, Agrofarm Cianjur perlu menambah mitra konsumen maupun sumberdaya manusia yang dimiliki. Penambahan mitra konsumen diperlukan agar dapat memperluas pasar dalam menjangkau segmen konsumen, sehingga produk yang dihasilkan dapat lebih dikenal. Perluasan pasar bisa dilakukan dengan menjangkau lebih banyak swalayan dan restoran yang menggunakan sayuran eksotik Jepang dan Korea. Dengan adanya hasil produksi yang berbeda dari kebanyakan petani pada umumnya tersebut, tentunya hal itu bisa menjadi peluang bagi Agrofarm Cianjur untuk dapat menjangkau konsumen lebih luas lagi. Seiring dengan adanya perluasan pasar, tentunya permintaan konsumen akan bertambah. Untuk memenuhi permintaan yang semakin banyak tersebut, Agrofarm Cianjur perlu menambah sumberdaya manusia agar produksi yang dihasilkan dapat maksimal dalam rangka memenuhi permintaan konsumen. Berdasarkan blok key activities, aktivitas administrasi Agrofarm Cianjur perlu menggunakan sistem komputer dengan 
menggunakan aplikasi Microsoft Excel dalam melakukan pencatatan administrasi setiap aktivitas produksi sampai penjualan, sehingga data dapat tersimpan dengan baik dan dapat meminimalisir dari hilangnya data.

\section{Daftar Pustaka}

Allee, V. (2000). Reconfiguring the Value Network. Journal of Business Strategy,21 (4).

Anonim. 2012. Business Model Canvas Penerapan di Indonesia. Jakarta (ID): Penerbit PPM.

Badan Pengembangan Sumberdaya Manusia Pertanian, 2007. Pedoman Penumbuhan dan Pengembangan P4S. (Internet). (Diunduh 6 September 2017). Tersedia pada: https://www.scribd.com/doc/56205695/Pedoman-Penumbuhan-DanPengembangan-P4S.

Badan Penyuluhan dan Pengembangan Sumberdaya Manusia Pertanian, 2017. Daftar P4S di Indonesia. (Internet). (Diunduh 7 September 2017). Tersedia pada: http://www.bbpp-lembang.info/index.php/database-kelembagaantani/p4s.

Badan Pusat Statistik Provinsi Jawa Barat, 2017.

Hasana, N. dan Hanum, L., 2016 Identifikasi Keuntungan Dan Faktor Non-Biaya Yang Mempengaruhi Harga Jual Horenso Di P4s Agrofarm Cianjur Jawa Barat. Jurnal Agrimart, 3 (01). 01-09.

Hasral, M. Dan Ibrahim, H., 2018. Budidaya Dan Segmentasi Pasar Lobak (Raphanus Sativus L.) Pada Pusat Pelatihan Pertanian Dan Pedesaan Swadaya (P4s) Agrofarm Cianjur- Jawa Barat. Jurnal Agrimart, 5 (01). pp. 1-13.

Kereh, B.M., 2015. Peranan Pusat Pelatihan Pertanian dan Perdesaan Swadaya (P4S) "Sahabat Tani" Dalam Meningkatkan Produktivitas dan Pendapatan Petani Bunga Potong Krisan di Kelurahan Kakaskasen Satu dan Dua. https://ejournal.unsrat.ac.id/index.php/cocos/article/viewFile/6807/633.

Kotler, Philip. 2008. Manajemen Pemasaran Edisi 12 Jilid 2. Jakarta: Indeks.

Osterwalder, A. dan Y. Pigneur. 2012. Business Model Generation. Jakarta: PT.Elex Media Komputindo.

Prasetyo, D. E., 2016. Pusat Pelatihan Pertanian Perdesaan Swadaya (P4s) Di Kecamatan Mojogedang. Skripsi Studi Arsitektur Fakultas Teknik Universitas Muhammadiyah Surakarta.

Sidiqon, K. and Raflis, H., 2017. Saluran Distribusi Labu Zucchini Di Pusat Pelatihan Pertanian Pedesaan Swadaya(P4s) Agrofarm Cianjur. Jurnal Agrimart, 4 (1). pp. 1-10.

Sugiyono. 2012. Metode Penelitian Kuantitatif Kualitatif dan RED. Yogyakarta: CV Alfabeta. 
Sugiyono. 2014. Memahami Penelitian Kualitatif. Bandung: CV Alfabeta.

Susilowati, S. H., 2016. Fenomena Penuaan Petani Dan Berkurangnya Tenaga Kerja Muda Serta Implikasinya Bagi Kebijakan Pembangunan Pertanian. Forum Penelitian Agro Ekonomi, Vol. 34 No. 1, Juli 2016: 35-55. 